\title{
The role of procedural, financial and relational switching costs in the Chinese online hotel booking market: antecedents and consequences
}

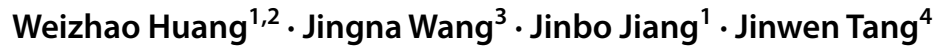

Received: 25 April 2020 / Revised: 2 April 2021 / Accepted: 12 April 2021 /

Published online: 15 May 2021

(c) The Author(s), under exclusive licence to Springer-Verlag GmbH Germany, part of Springer Nature 2021

\begin{abstract}
This study reveals the key facets of switching costs and their antecedents within the context of online hotel booking in China using mixed methods. Survey results based on 368 valid responses indicate significant antecedents stemming from the characteristics of the online booking market and the individual behavioural and experiential characteristics of customers. However, relational switching costs show a significant positive effect on customers' intentions to continue with their current online booking service provider, while other switching costs do not. Qualitative research further explores the multi-dimensional nature of customer-perceived switching costs and shows that consumers' habitual purchases with an online hotel booking service provider form trust, increasing the cost of brand relationship losses and preventing customers from switching. When the self-construal of consumers is different, the homogeneity of providers will have both a positive and negative impact on switching intentions. There are also some interesting findings regarding learning costs in the online hotel booking field. This study extends knowledge about customer retention in the competitive Chinese online booking market by incorporating different types of antecedents and testing their influences on different facets of switching costs as well as the consequences.
\end{abstract}

Keywords Switching costs - Online hotel booking $\cdot$ Market characteristics $\cdot$ Provider heterogeneity $\cdot$ Extent of modification $\cdot$ Alternative experience $\cdot$ Customer retention

Jingna Wang

Wangjn@nankai.edu.cn

1 Department of Tourism Management, South China University of Technology,

Guangzhou 510006, China

2 Department of Tourism Management, Guangdong Tourism Vocational Institute, Guangzhou 510515, China

3 College of Tourism and Service Management, Nankai University, Tianjin 300071, China

4 College of Management, Guangdong Polytechnic Normal University, Guangzhou 510665, China 


\section{Introduction}

With the growth in information and communication technology (ICT), an increasing number of consumers purchase travel products directly on hotel websites or through online travel agencies (OTAs) (Silva et al. 2019; Nathan et al. 2020; Gellerstedt and Arvemo 2019). Relying on OTA and hotel websites, consumers can book hotel accommodations by pressing a button on their personal electronic device. Through refined operation and product innovation, online booking platforms make consumers' search and booking experience more fluid, more personalized and more cost-effective with lower price, continuous transaction quotations and a series of value-added services. In addition, under the influence of the spread of COVID-19 in 2020, customers have begun to prefer non-contact services supported by digital platforms and intelligent technologies, and this preference is expected to continue in the future (Hao et al. 2020).

Relevant data show that China's online hotel booking industry has maintained obvious rapid growth, becoming an important part of the global hotel booking market (Tao et al. 2018). However, despite these exciting developments, Chinese online hotel booking providers still face tremendous pressure to survive. The gradual saturation of internet users has increased the cost of acquiring customers (Hao et al. 2020). The online hotel booking market traffic is obviously concentrated, and services tend to be homogenized. Non-traditional accommodation online booking platforms representing new business models (e.g., Airbnb) are constantly emerging (Varma et al. 2016). As a result, online booking service providers must conduct many marketing efforts to improve customer loyalty and stickiness; in other words, many businesses would like to improve customer perceived switching cost to retain their customers (Barroso and Picón 2012).

Although there is a consensus on the importance of perceived switching costs (PSCs), only a few studies have attempted to analyse the antecedents, outcomes and hierarchy of importance among the dimensions of PSC (Barroso and Picón 2012). Some studies from the service research field have sought to fill this gap; for example, some studies consider PSCs to be a subcomponent of switching barriers to evaluate their roles in the domestic and international hotel industry (e.g., Han et al. 2011a, b). However, people rarely pay attention to the switching costs of online hotel booking. There is very limited insight into how hotel booking platforms create specific switching costs for different customer segments to cultivate loyalty to providers. Therefore, this study contributes to the body of knowledge on the intricate relationships among PSCs and the antecedents and consequences of switching costs within the context of online hotel booking to fill the gaps in the literature. Specifically, this research focuses on two research questions:

RQ 1. What are the salient facets of PSCs within the context of online hotel booking, and how do they influence customers' intentions to continue with the same online booking platform?

RQ 2. What are the relationships among different types of antecedents and PSCs within the context of online hotel booking? 
To answer these two questions, this research used quantitative and qualitative methods because quantitative methods alone may reduce the impact of contextual materials while mixed research methods would allow for complementary and richer data sets (Gu and Ryan 2010). The quantitative study found that the industrial characteristics of PSCs in the hotel online booking market, that is, relationship loss costs contribute the most to the formation of the PSC construct. Qualitative research further uncovers unexplained aspects from the results of the quantitative study (Koo et al. 2020a) to explain interrelationships among switching costs and the antecedents and consequences within the context of online hotel booking.

\section{Theoretical background}

\subsection{Conceptual framework}

Consistent with the work of some scholars (Edward and Sahadev 2011; Patterson 2004), this research applies social exchange theory to develop a conceptual model. As Blau (1964) noted, social exchange refers to "individual behaviours that are encouraged by the return they are expected to obtain from others". Thus, the extent to which individuals would like to remain in an exchange relationship is proportional to the satisfaction they receive from the existing relationship (Edward and Sahadev 2011). Patterson (2004) justifies the use of social exchange theory as a foundation of switching costs in the service industry. As he noted, whether people like to remain in an existing relationship or switch to others is reliant on certain factors such as switching cost, past experiences, and even the characteristics of individual costumers (Patterson 2004). Therefore, in this study, switching cost is posited as influencing the inclination of customer purchasing and retention. Additionally, social theory indicates that switching behaviour is influenced by the characteristics of individual customers and companies.

\subsection{Measuring perceived switching costs within the context of online hotel booking}

PSCs can be defined as the costs associated with the transfer of customers from one service or product provider to another service or product provider (Heide and Weiss 1995). In other words, PSCs are the sacrifice or the punishment that customers must incur (Jones and Taylor 2007). Since switching is a dynamic process the extends from the termination of existing costs and benefits to the acceptance of new providers, the relevant costs include all costs that customers face from the beginning of the provider switching decision to the final execution (Roos et al. 2002). In previous research, clarity and consensus on the uni-dimensional or multi-dimensional structural characteristics of PSCs have been lacking. Some studies use a onedimensional structure (Arasil et al. 2005; Kim and Cho 2014; Zhang et al. 2019), which is thought to ignore the complexity of the structure (Lam et al. 2004). People are increasingly aware of the multi-dimensional nature of PSCs (Barroso and Picón 
2012). For example, Burnham et al. (2003) found eight different consumer switching costs (economic risk costs, evaluation costs, learning costs, set-up costs, benefit loss costs, monetary loss costs, personal relationship loss costs and brand relationship loss costs), and these eight switching costs include three higher-level switching cost types: procedural, financial and relational switching costs. Additionally, a literature review by Barroso and Picón (2012) reveals that PSCs have a high-level formative structure composed of six first-order dimensions (benefit loss costs, personal relationship loss costs, economic risk costs, evaluation costs, set-up costs and monetary loss costs); these dimensions involve the effort, time and money invested by customers (Barroso and Picón 2012). They also tested the antecedents of PSCs and identified two sets of them that are based on relationship characteristics and customer characteristics. Others have described different types of switching costs, such as "positive" and "negative" switching costs (Jones et al. 2000).

Online hotel booking providers, regardless of whether they are OTAs that attract customers with a large amount of hotel information, price comparisons, discounts and reviews (Chang et al. 2019) or hotel websites that belong to the hotels themselves, all face new challenges: understanding and determining the key factors for customers to switch to other providers and promoting customer retention. Recent research has focused more on loyalty programmes, switching barriers, or perceived risks (e.g., Chang et al. 2019; Koo et al. 2020b; Jesus Lopez-Miguens and Gonzalez Vazquez 2017). To the best of our knowledge, no prior work has investigated the switching costs and their antecedents in online hotel bookings, even though understanding these issues is vital for today's online travel industry.

Since a multi-dimensional perspective can provide significant management advantages (Barroso and Picón 2012), this study builds upon the typology by Burnham et al. (2003) who consider the procedural, financial, and relationship costs in the initial pool of PSCs because their typology constitutes one of the few in-depth analyses and tests of the causes and results of each dimension (Barroso and Picón 2012). To address the gap noted above, this paper examines different aspects of PSCs and aims to identify what dimensions of PSCs are salient within the context of online hotel booking. Building upon the typology by Burnham et al. (2003), we consider the procedural, financial and relational costs in the initial pool of PSCs.

\subsection{Procedural, financial and relational costs within the context of online hotel booking}

Burnham et al. (2003) identified eight facets of switching costs that fall into three types of PSCs: procedural, financial and relational costs. In general, procedural switching costs primarily involve the expenditure of time and effort including economic risk, evaluation, learning, and set-up costs. Financial switching costs primarily involve the loss of financially quantifiable resources including benefit loss and monetary loss costs. Relational switching costs primarily involve psychological or emotional discomfort due to the loss of identity and the breaking of bonds including personal relationship loss and brand relationship loss costs (Burnham et al. 2003). 
Table 1 summarizes the definition of each facet of PSCs contextualized in the online hotel booking scenario.

Although all facets in Table 1 are referred to as PSCs, it is important to differentiate how they are perceived and to thus place different impacts on customers' intentions to continue using a certain online booking platform. Procedural switching costs are primarily associated with the uncertainty of the time and effort to be invested in the new service (Burnham et al. 2003). The higher the procedural switching costs are perceived to be, the greater the time and effort that will be required to use the service of a new online hotel booking platform, which will result in a lower willingness to switch. However, financial and relational switching costs are primarily associated with the loss of financial or affective benefits when leaving the current online hotel booking platform. Higher switching costs cause customers to feel bound by relationships (Aydin and Özer 2005). People will think that they will suffer a greater loss, which may lead them to be more willing to continue using the original online booking platform (Burnham et al. 2003). The battle between the switching risk and loss will then determine the overall intention to continue using the original online booking platform.

Due to the pervasiveness of mobile technology diffusion, learning costs and setup costs have almost been reduced to a minimum; thus, individuals of any age and any background can have easy access to online hotel booking services. The monetary loss costs are also zero as there is no charge when switching to a new online hotel booking platform. Additionally, the personal relationship loss costs are no longer a concern due to the maturity of human-computer interfaces powered by the rise of artificial intelligence. Consequently, the personal relationship between customers and company staff rarely develops into a switching barrier. Given such reasons, learning costs, set-up costs, monetary loss costs and personal relationship loss costs fall beyond the scope of this study.

\subsection{Antecedents of perceived switching costs}

Considering the antecedents of PSCs, we observe that some customers might perceive only the switching costs associated with leaving a current online hotel booking platform and not perceive the cost of beginning a new relationship with an alternative provider. In other words, some customers may be aware of only the financial switching cost and be unaware of any procedural cost. Such a failure might happen due to the lack of knowledge that customers have about different service providers in the market (Barroso and Picón 2012). To address this issue, both market-related and individual behaviour-related antecedents are investigated in this paper.

Prior research suggests that PSCs have three types of antecedents: (1) perceptions of market characteristics, (2) investments in the current service provider, and (3) domain expertise (Burnham et al. 2003). Market characteristics include product/service complexity and provider heterogeneity. Within the context of online hotel booking, product/service complexity is relatively low across all major providers as they have optimized their service into an easy-to-use and mobile-friendly format with the diffusion of mobile technology (Ozturk et al. 2016). Therefore, this paper focuses on 


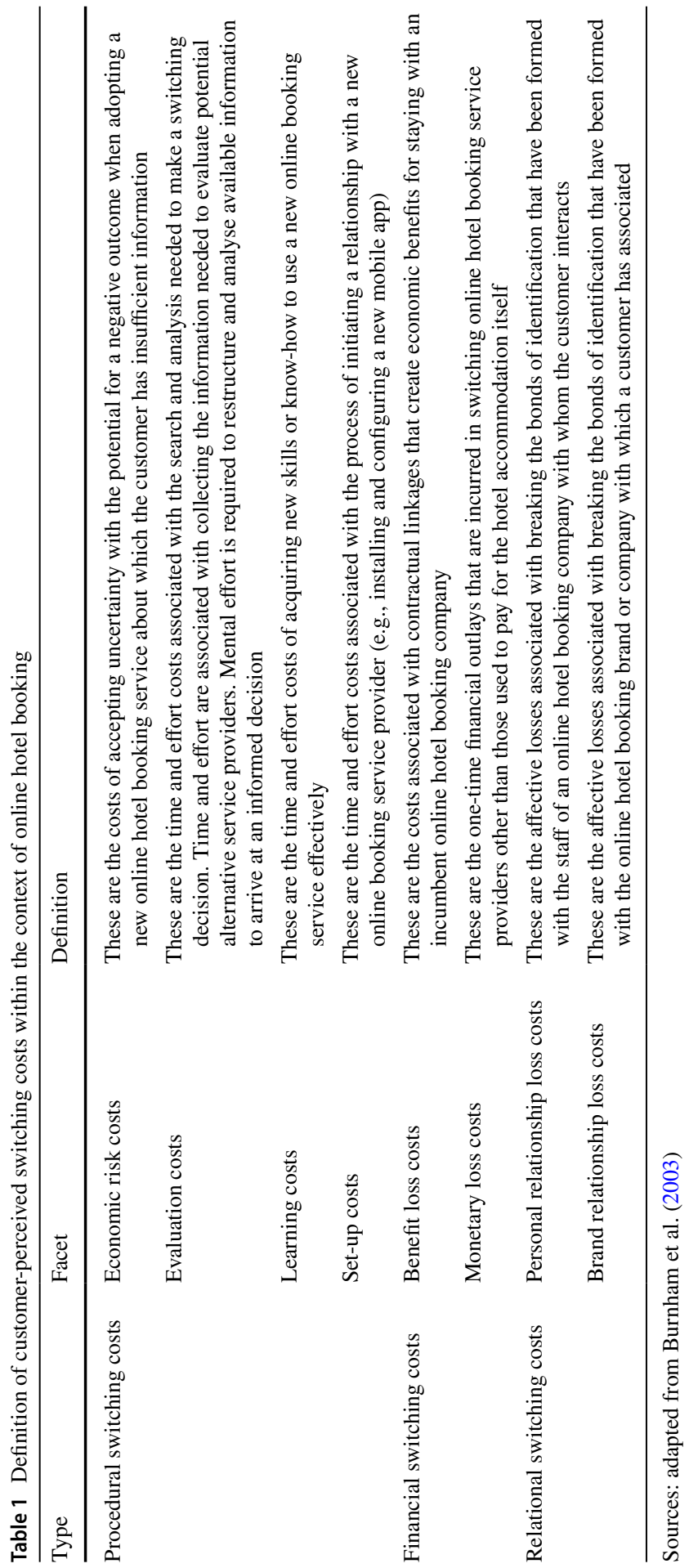


the PSC antecedent provider heterogeneity, which is defined as the extent to which providers in the online hotel booking market are seen as different or non-substitutable (Burnham et al. 2003). Some online providers' sources, such as the security of and/or trust in OTAs, online destination marketers or hoteliers, influence consumers' decision-making through their attitudes (Kim et al. 2005). Provider heterogeneity is also reflected in the characteristics of websites themselves, such as convenience, time savings, and easy-to-compare prices, which are key drivers of online purchasing decisions (Morosan and Jeong 2008). Burnham et al. (2003) pointed out that by enhancing customers' perceptions of provider heterogeneity, it is possible to increase their relational switching costs.

Investments in the current service provider include breadth of use and the extent of modification. Breadth of use is defined as the extent to which the customer employs a variety of service types, features, and functions offered by a provider (Ram and Jung 1990). Since the scope of this paper is delimited to include solely the use of online hotel booking services, the extent to which customers use other service types and features is not considered. The extent of modification is defined as the extent to which the customer adapts the service offered so that it better serves his or her individual needs (Burnham et al. 2003). As a typical example, customers adapt their profile set-up behaviour so that they can obtain better customized offers from online hotel booking providers (Barroso and Picón 2012). For mainland Chinese travellers, providing appropriate levels of switching barriers, such as irreplaceable services, will not only increase customer dependence but also reduce the attractiveness of competitors (Qiu et al. 2015).

Domain expertise allows customers to evaluate alternative services and learn new services more rapidly and accurately (Burnham et al. 2003). It consists of alternative experience and switching experience. Alternative experience is considered to be the breadth of experience that the customer has with the various services, features, and functions offered by a competing service provider (Burnham et al. 2003). Switching experience is defined as the extent to which the customer has switched between providers in the past (Burnham et al. 2003). Both types of experience allow customers to be aware of the uncertainty associated with new services (i.e., procedural switching costs) and the potential financial and relational losses (i.e., financial and relational switching costs). The more alternative experience or switching experience a customer has had, the more knowledge on competing service providers he or she will have, and therefore the lower the extent to which risks will be perceived when switching.

However, it is not necessarily the case that all customers will have switching experience as they might have stayed with the same service provider since they started using online booking services. For instance, some statistics indicate that two brands control well over $90 \%$ of the online hotel booking market in the US (Jennings 2018) and that two-thirds of high-frequency travellers stay at hotels belonging to the same brand for more than half of their travel days regardless of location (Jennings 2014). Therefore, in this study, alternative experience is investigated as a PSC antecedent, and switching experience is treated as a control factor.

Empirical studies have found mixed support for the relationships among antecedents and PSCs in several industries (Barroso and Picón 2012; Blut et al. 2015; Han 
et al. 2011a, b). Thus, it is crucial for this paper to test the relationships within the online hotel booking context. Additionally, there is a lack of evidence in the hospitality industry that provides insights for an integrated view of the relationships among the three types of antecedents and switching costs.

Based on the existing literature and the above literature review, the following hypotheses are proposed:

H1: Provider heterogeneity has a positive effect on PSCs.

H2: The extent of modification has a positive effect on PSCs.

H3: Alternative experience has a negative effect on PSCs.

\subsection{Switching costs and customers' intentions to continue using a certain online booking platform}

For customers, switching costs act as barriers to switching from one service provider to another (Guiltinan 1989). Therefore, the primary role of switching costs is to induce customer loyalty and gain customer retention (Edward and Sahadev 2011). The positive effect between switching costs and customers' intentions to continue using a certain product or service has been found by many empirical studies (Arasil et al. 2005; Burnham et al. 2003; Jones et al. 2000; Kim et al. 2006; Li and Gan 2015; Su et al. 2011). The higher the perceived switching costs are, the stronger the switching barriers will be, and the higher the value that customers will place on existing relationships (Fornell 1992).

When consumers book hotel accommodations on the Internet, several advantages are provided to them, such as convenience, good price comparison, low costs, and the provision of up-to-date and accurate information (Teng et al. 2020). For this reason, online booking has become a useful tool for consumers to purchase tourism products and communicate information (Teng et al. 2020). However, even though customers have many websites (OTAs, hotel websites and referral sites) as a variety of available alternative choice sets, information overload causes customers to exert more effort to make a decision, thereby decreasing their purchase willingness with respect to new providers (Guillet et al. 2019). In this decision process, economic risk costs form a barrier to switching to new providers.

Hotel online bookings gather most of the traffic of online travel platforms (Vryona 2014). However, with regard to the typical experiential consumption of hotel accommodations, their remoteness and intangible service consumption characteristics make it impossible for consumers to accurately assess the content and quality of such services before booking. A large amount of information needs to be referred to before decision-making to reduce perceived risk (Klein 1998). Although some consumers are satisfied with the hotel product information provided by a new online provider, the lack of relevant consumer reviews may lead to the termination of this booking behaviour. The perceived evaluation costs, such as the time and effort required to select an appropriate service provider, are reduced based on issues of trust (Ponte et al. 2015). Higher perceived evaluation costs produce a greater inclination for consumers to choose the original provider. 
Switching costs are usually associated with loyalty programmes with specific programme benefits. Consumers can redeem their points for hotel accommodations, restaurant meals and complimentary casino items (Tanford 2016). If customers change their online hotel bookings, this actual or implied monetary value causes customers to have to sacrifice money, benefits, points and product value (Tanford 2016). The contractual linkages created by benefit loss costs prevent customers from turning to new providers (Burnham et al. 2003).

Brand awareness is a necessary precondition for choice (Nedungadi 1990). When consumers are engaged in routine purchases or have high brand loyalty, they tend to use simple decision rules to make an online booking decision (Sangwon et al. 2018). That is, a brand image significantly influences customers' trust in online booking providers, and it can improve consumer purchase intentions. Studies have found that online purchases are typically dependent on consumers' trust in providers (El-Said 2020). Switching costs lead to relationship maintenance and have a positive impact on customer loyalty to OTAs (Porter 1980). Inline with the existing literature, this paper hypothesizes the following:

H4: Economic risk costs have a positive effect on customers' intentions to continue using a certain online booking platform.

H5: Evaluation costs have a positive effect on customers' intentions to continue using a certain online booking platform.

H6: Benefit loss costs have a positive effect on customers' intentions to continue using a certain online booking platform.

H7: Brand relational loss costs have a positive effect on customers' intentions to continue using a certain online booking platform.

Accordingly, the priori conceptual model shown as Fig. 1 is presented to illustrate the conceptual framework and hypotheses based on the literature review.

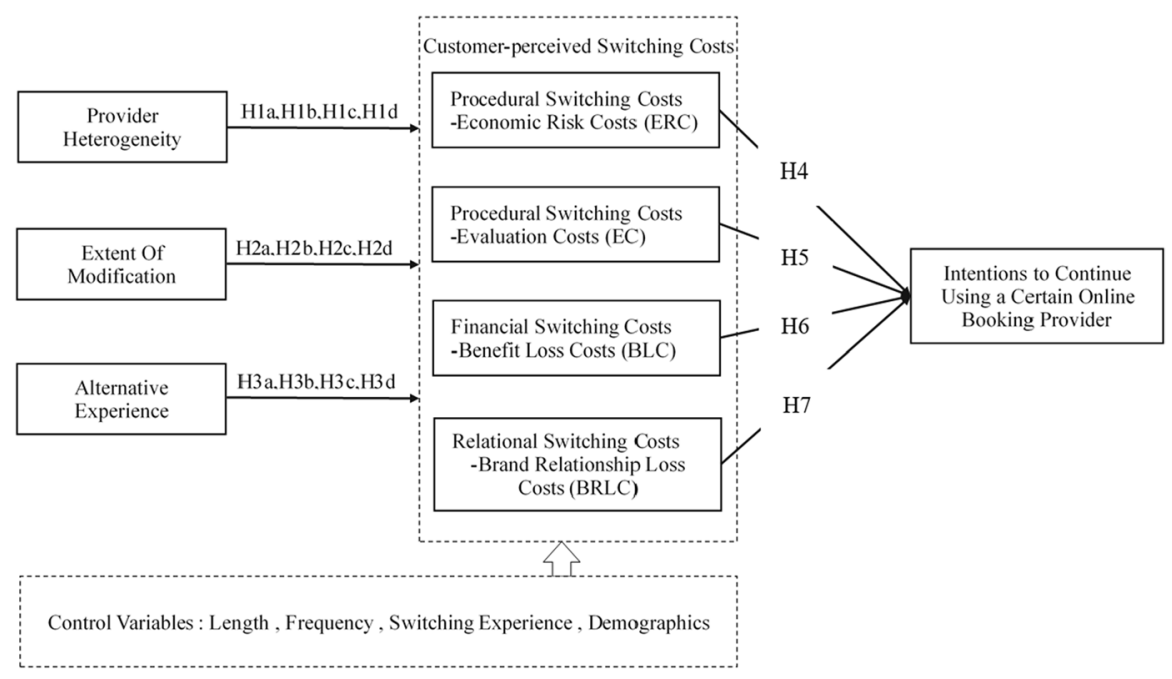

Fig. 1 Conceptual framework 


\section{Methodology}

\subsection{Research design}

This study employed an explanatory sequential mixed-methods design to obtain a deeper understanding and to provide a more comprehensive answer to the given research problems within online hotel booking (Creswell and Clark 2006). As many researchers advocated, the research paradigm of mixed method is pragmatism, (Johnson and Onwuegbuzie 2004; Johnson et al. 2007; Feilzer 2010; Tashakkori and Teddlie 2010), because mixed method emphasizes the practicality and background of research, and advocates that research questions determine research methods.

A two-phase data collection process was conducted. Phase 1 involved a quantitative study to empirically test the conceptual framework and hypotheses based on the literature review. Then, to help examine outliers and explore the quantitative analysis (Morse 1991), phase 2 involved the use of quantitative results to initiate the grounded theory analysis to provide further explanation and description of those results (Creswell and Clark 2006). The grounded theory data collection methods flow from the research question (Charmaz 2006). When qualitative research allows researchers to discern explicit and implicit processes in their data, grounded theory offers a useful means of studying processes to study phenomena in depth (Charmaz 2019; Corbin and Strauss 1990). Thus, this research employed grounded theory strategies to define the relative facets of PSCs and their relationships (Charmaz 2019).

\subsection{Study 1: quantitative phase}

\subsubsection{Quantitative sample}

The measurement items were adapted from the previous literature and translated into Mandarin. Therefore, to ensure the quality of the measurement items in the questionnaire across different languages and cultural contexts, we used a team approach to translate the scale in a two-way translation process. The translated items were checked by three experts whose first language is Mandarin and then refined until agreement was reached. A pilot test involving 95 online hotel booking customers (166 respondents completed the survey, but 71 were filtered out due to their inactive status in online hotel booking) was conducted. The pilot survey results indicated some poor loadings from the reverse-coded items. Therefore, two items were eliminated, and an adequate level of measurement reliability and validity was obtained. The refined measurement items for each construct utilized in this study are presented in Appendix 1.

The main survey was distributed via two channels between February and April 2019: WeChat and the Sojump survey company. WeChat is the dominant social networking site in China, having over 806 million monthly active users in the second quarter of 2016 (Statista 2016); the Sojump survey company is an online panel 
service provider in China with a pool of 2.6 million samples (Consulting and David 2014). A snowball sampling technique was used to collect data via WeChat. The subjects who participated in the pilot study were asked to distribute the survey questionnaire link in their WeChat friend groups. Only respondents who passed the filter questions and the attention check questions were considered valid response sources. A pool of 2000 customers were invited to participate in the survey, and 368 valid responses were obtained. Structural equation modelling (SEM) was adopted, and Smart PLS 3.0 was used to analyse the survey data.

The self-reported place of residence of the 368 respondents indicated that they were from 13 provinces or municipalities in China, and approximately $25 \%$ were from the four first-tier cities (Beijing, Shanghai, Guangzhou, Shenzhen). Other demographic data (Appendix 2) indicated that there was no dominant population in our sample. The extent of respondents' online hotel booking usage was also recorded by asking about the length of their membership with the main online platform they use and the frequency of usage of this platform (Appendix 2). Altogether, the distribution of our respondents indicated a good level of representativity.

Upon completion of data collection, potential non-response bias was investigated by comparing the early and late participant responses (Armstrong and Overton 1977). Based on a t test comparison of the early one-third and late one-third of responses, no significant differences in the major constructs were found, indicating that non-response bias is not a concern in this research.

\subsubsection{Measurement model}

Reliability and convergent validity were examined by assessing Cronbach's alpha, composite reliability and the average variance extracted (AVE) (Hair et al. 1998). As reported in Table2 the composite reliability and Cronbach's alpha of the reflective constructs both exceeded the threshold of 0.70, suggesting good reliability for all constructs (Nunnally 1978). All AVE values were above the recommended cut-off value of 0.5 . Additionally, the item loadings for all constructs were above 0.70 , suggesting good convergent validity (Barclay et al. 1995) (see Table 2).

Table 2 Reliability and construct validity

\begin{tabular}{lllll}
\hline & Cronbach's alpha & Rho_A & $\begin{array}{l}\text { Composite } \\
\text { reliability }\end{array}$ & $\begin{array}{l}\text { Average variance } \\
\text { extracted (AVE) }\end{array}$ \\
\hline Alternative experience & 0.801 & 0.855 & 0.820 & 0.700 \\
Benefit loss costs & 0.912 & 0.913 & 0.912 & 0.776 \\
Brand relationship loss costs & 0.726 & 0.727 & 0.726 & 0.570 \\
Economic risk costs & 0.808 & 0.811 & 0.807 & 0.583 \\
Evaluation costs & 0.892 & 0.897 & 0.893 & 0.737 \\
Extent of modification & 0.839 & 0.844 & 0.839 & 0.636 \\
Intentions to continue & 0.800 & 0.905 & 0.837 & 0.729 \\
Provider heterogeneity & 0.722 & 0.725 & 0.723 & 0.567 \\
\hline
\end{tabular}


Discriminant validity was assessed by comparing the square roots of the AVE value for each construct and the correlation between one construct and the other constructs (Fornell and Larcker 1981) (see Table 3). HTMT (heterotrait-monotrait) matrix and cross loadings provide additional support for discriminant validity (Appendices 3 and 4).

Moreover, Kock and Lynn proposed the full collinearity test as a comprehensive procedure for assessing the severity of common method bias (Kock 2015; Kock and Lynn 2012). A VIF of greater than 3.3 is considered to be an indicator that a model may be contaminated by common method bias (Kock 2015). This study shows that all VIFs are lower than 3.3, demonstrating that our data are free from common method bias (Appendix 5).

\subsubsection{Results of structural model}

The results of the structural model analysis are presented in Fig. 2, with details presented in Table 4. The results provide supporting evidence on which types of antecedents have a significant impact on PSCs and which types of PSCs significantly influence customers' intentions to continue using a certain online booking platform.

First, the effect of PSCs on intentions to continue using a certain online booking platform is shown by the path coefficient sizes and significance as well as the $\mathrm{R}^{2}$ values. The path coefficient sizes and significance demonstrate the significant influence of PSCs on intentions to continue using a certain online booking platform. Specifically, only brand relationship loss costs are significantly associated with intentions to continue using a certain online booking platform $(\beta=0.679, \mathrm{p}<0.001)$. Therefore, $\mathrm{H} 7$ is supported, while the hypothesized links between other types of PSCs and intentions to continue using a certain online booking platform are not supported. These hypothesis (H4, H5, H6) are not supported, which may be due to the following: the third-party online payment service solutions have been adopted by many online providers, and consumers do not need to worry about economic risks when making a decision to switch providers. Due to the high concentration of online hotel booking, top brands have strong brand awareness and customer bases. Most consumers are members of several top brands at the same time, and they can easily switch to competitors' platforms to search for and obtain their target products without too much effort; thus, the evaluation cost may not have a significant influence on continuing purchase intention. Benefit loss cost often comes from the provider's membership benefits and bonus points. Because online providers usually set acquisition rules, expiration dates, and usage thresholds, the complicated procedures cause consumers to become bored and ignore them. This may cause the relationship of H6 to be insignificant. In addition, the $\mathrm{R}^{2}$ value for intentions to continue using a certain online booking platform is 0.456 , indicating that all PSC variables (economic risk costs, evaluation costs, benefit loss costs, brand relationship loss costs) together explain $45.6 \%$ of the variance in intentions to continue using a certain online booking platform. Because the coefficient sizes and significance between brand relationship loss costs and intentions to continue using a certain online booking platform are very strong but other relationships are nonsignificant, it is worth examining the quantitative findings to understand why this is the case. 


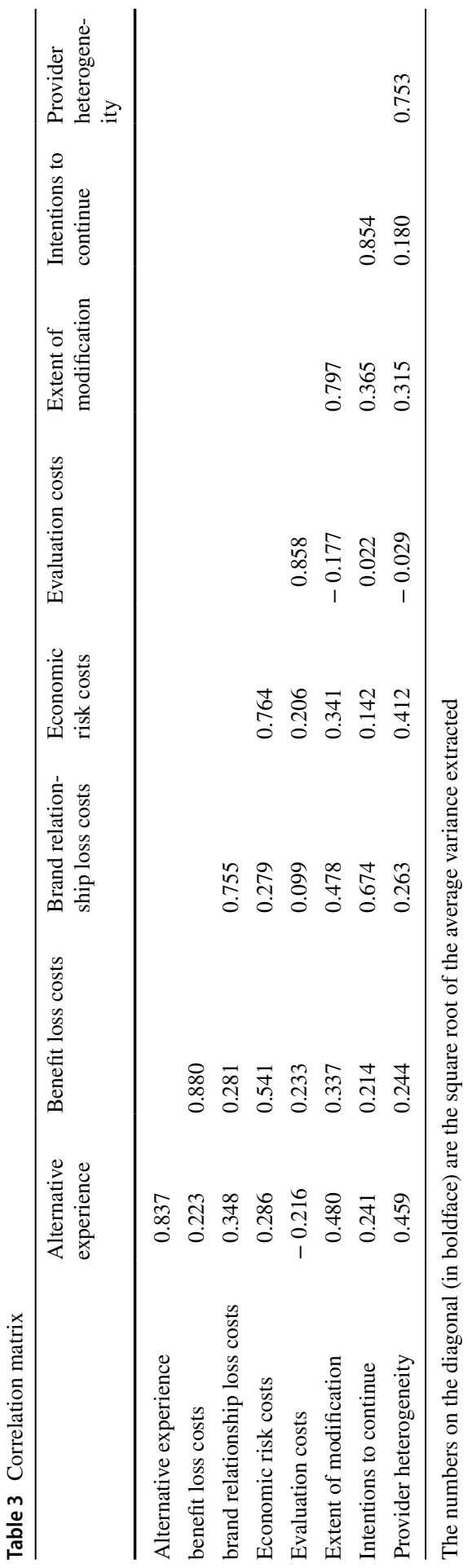




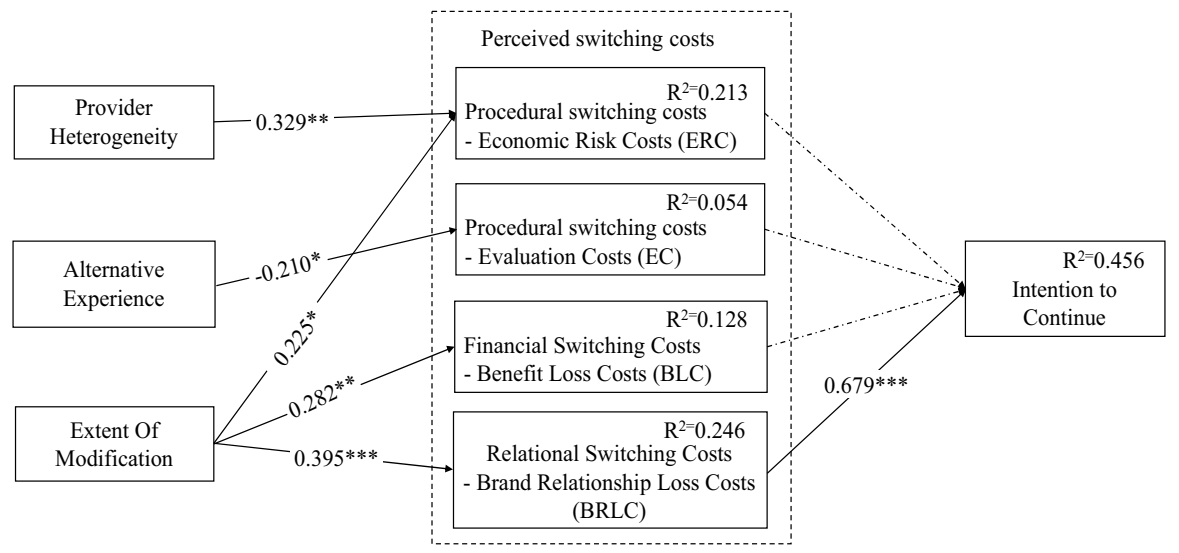

Fig. 2 The structural model. *p $<0.05, * * \mathrm{p}<0.01, * * * \mathrm{p}<0.001$

Table 4 Results of the structural model and hypothesis testing

\begin{tabular}{lrll}
\hline Hypotheses & \multicolumn{1}{l}{$\beta$} & P Values & Supported or not \\
\hline Provider heterogeneity $\longrightarrow$ economic risk costs & 0.329 & 0.001 & H1a supported \\
Provider heterogeneity $\longrightarrow$ evaluation costs & 0.101 & 0.270 & H1b not supported \\
Provider heterogeneity $\longrightarrow$ benefit loss costs & 0.147 & 0.138 & H1c not supported \\
Provider heterogeneity $\longrightarrow$ brand relationship loss costs & 0.085 & 0.379 & H1d not supported \\
Alternative experience $\longrightarrow$ economic risk costs & 0.026 & 0.796 & H2a not supported \\
Alternative experience $\longrightarrow$ evaluation costs & -0.210 & 0.015 & H2b supported \\
Alternative experience $\longrightarrow$ benefit loss costs & 0.020 & 0.837 & H2c not supported \\
Alternative experience $\longrightarrow$ brand relationship loss costs & 0.118 & 0.298 & H2d not supported \\
Extent of modification $\longrightarrow$ economic risk costs & 0.225 & 0.017 & H3a supported \\
Extent of modification $\longrightarrow$ evaluation costs & -0.109 & 0.175 & H3b not supported \\
Extent of modification $\longrightarrow$ benefit loss costs & 0.282 & 0.001 & H3c supported \\
Extent of modification $\longrightarrow$ brand relationship loss costs & 0.395 & 0.000 & H3d supported \\
Economic risk costs $\longrightarrow$ intentions to continue & -0.080 & 0.217 & H4 not supported \\
Evaluation costs $\longrightarrow$ intentions to continue & -0.046 & 0.378 & H5 not supported \\
Benefit loss costs $\longrightarrow$ intentions to continue & 0.077 & 0.249 & H6 not supported \\
Brand relationship loss costs $\longrightarrow$ intentions to continue & 0.679 & 0.000 & H7 supported \\
\hline
\end{tabular}

Second, the effect of the antecedents on PSCs is shown by the path coefficient sizes and significance as well as the $\mathrm{R}^{2}$ values. The path coefficient sizes and significance demonstrate the significant influence of the antecedents on PSCs. Specifically, provider heterogeneity $(\beta=0.329, \mathrm{p}<0.01)$ and the extent of modification $(\beta=0.225, \mathrm{p}<0.05)$ are significantly associated with economic risk costs; alternative experience is significantly associated with evaluation costs only $(\beta=-0.210$, $\mathrm{p}<0.05)$; the extent of modification is significantly associated with benefit loss costs $(\beta=0.282, \mathrm{p}<0.01)$ and brand relationship loss costs $(\beta=0.395, \mathrm{p}<0.001)$. 
Therefore, H1a, H2b, H3a, H3c, and H3d are supported, while the other hypothesized links between the antecedents and PSCs are not supported. There is no significant path between the online booking provider heterogeneity perceived by consumers and the evaluation cost, economic cost, and brand relationship lost cost (H1b, H1c, H1d). This may be due to the fact that the hotel booking industry is currently highly concentrated, the business model is mostly similar, and digital operation is more transparent (Yin 2016); thus, customers perceive that the heterogeneity between providers is not obvious, and it is easy for customers to switch between different providers. This may explain the insignificance of H1b. When a provider does not have obvious financial constraints on customers, the relationship between customer perception of online booking provider heterogeneity and economic costs and brand relationship lost costs is not significant. Another reason may be the "uncertainty avoidance" culture dimensions proposed by Hofstede (1984): the higher heterogeneity of providers, the greater uncertainty of costs and services perceived by consumers after switching. Compared with the more certain search effort, loss of profit and the end of brand relationship caused by switching, people will pay more attention to the uncertain aspect, which is mainly reflected in the increase of economic risk cost. Moreover, this may be due to the fact that many consumers are members of several top brands at the same time. Such consumers value the final hotel products and do not particularly care who provides them with the product. Customers with multiple platform memberships may not have obvious losses in terms of economic risk costs, benefit lost costs, and brand relationship lost costs. These reasons may lead to $\mathrm{H} 2 \mathrm{a}, \mathrm{H} 2 \mathrm{c}, \mathrm{H} 2 \mathrm{~d}$ not being supported.

Additionally, the $\mathrm{R}^{2}$ values for the three types of PSCs are relatively good: for economic risk costs, benefit loss costs, and brand relationship loss costs, these values are $0.213,0.128$, and 0.246 , respectively. However, the $\mathrm{R}^{2}$ value for evaluation costs is very low, 0.054 . This result indicates that all three antecedent variables together explain only $5.4 \%$ of the variance in evaluation costs.

Furthermore, the test involving the control variables (gender, age, education, income, the length of membership with the main online platform, and the frequency of usage of this platform) indicates that none of the estimated paths is statistically significant. Additionally, switching experience is not significantly associated with intentions to continue using a certain online booking platform. As a result, the control variables had a nonsignificant impact on PSCs or intentions to continue using a certain online booking platform.

Although there is still a lack of clarity and consensus on the uni-dimensional or multi-dimensional structural characteristics of PSCs (Barroso and Picón 2012), people have gradually realized that PSCs have multi-dimensional characteristics. Based on the existing literature, we propose multi-dimensional PSCs in the context of online hotel bookings: economic risk costs, evaluation costs, benefit loss costs, and brand relational loss costs. However, analysis of the results shows that only brand relational loss costs are significantly related to customer retention. At the same time, the explanatory power of the three antecedent variables for evaluation costs is very low. This result sparked our interest in conducting further exploration. Due to the different natures of switching costs in different industries (Fornell 1992), and because the research on the antecedents and consequences of PSCs in online 
hotel booking remains relatively unexplored, we adopted an explanatory sequential mixed-methods design to further explore the facets and influencing factors of PSCs, leading to a more comprehensive understanding of the antecedents and consequences of PSCs. This strategy is very useful when unexpected results appear in quantitative research (Morse 1991).

\subsection{Study 2: qualitative phase}

\subsubsection{Data collection and analysis}

The data sources for this study include in-depth interviews, participant observations and related media reports. The 10 respondents (4 males and 6 females), including occupational workers and postgraduate students, were between 20 and 45 years old and come from eastern and southern China. All interviews lasted more than $25 \mathrm{~min}$ and were audiotaped with permission and transcribed verbatim into text data of approximately 23 thousand Chinese characters. The interview questions covered PSCs, the antecedents of PSCs, switching intentions and customer retention. The procedures of data collection and analysis were carried out systematically and sequentially until the data repeated and no more new categories and dimensions appeared, thus achieving theoretical saturation to ensure the effectiveness of the grounded theory approach (Corbin and Strauss 1990). Three coding steps were used to explore the antecedents and consequences of PSCs. To make the coding process more standardized, we used NVivo 12 qualitative analysis software for data sorting and analysis.

\subsubsection{Results}

This research conducted a three-level coding of the interview data using NVivo 12, in which 597 original statements, 47 concepts and 22 categories were obtained. Figure 3 explains the final data analysis framework. Based on the data analysis, we determined the five potential factors in the causal model of switching costs: antecedents of switching costs, perceived switching costs, the triggers of switching, selfconstrual and switching intentions.

Figure 4 presents the generation path and evolution mechanism model for the antecedents and consequences of customer switching costs in the context of online hotel booking platforms.

Antecedents of switching costs The antecedents of switching costs include the heterogeneity and homogeneity of providers, customers' extent of modification, alternative experience and switching experience.

Provider heterogeneity If providers show obvious heterogeneity in the quality and functions of their websites, customers' brand relationship loss costs rise. In other words, customers form a sense of belonging, trust and dependence with regard to familiar platforms. For example, interviewee No. 2 believes that a family bond exists between him/her and the provider, which brings a sense of safety; furthermore, this brand relationship will suffer once he or she switches to a new platform. 


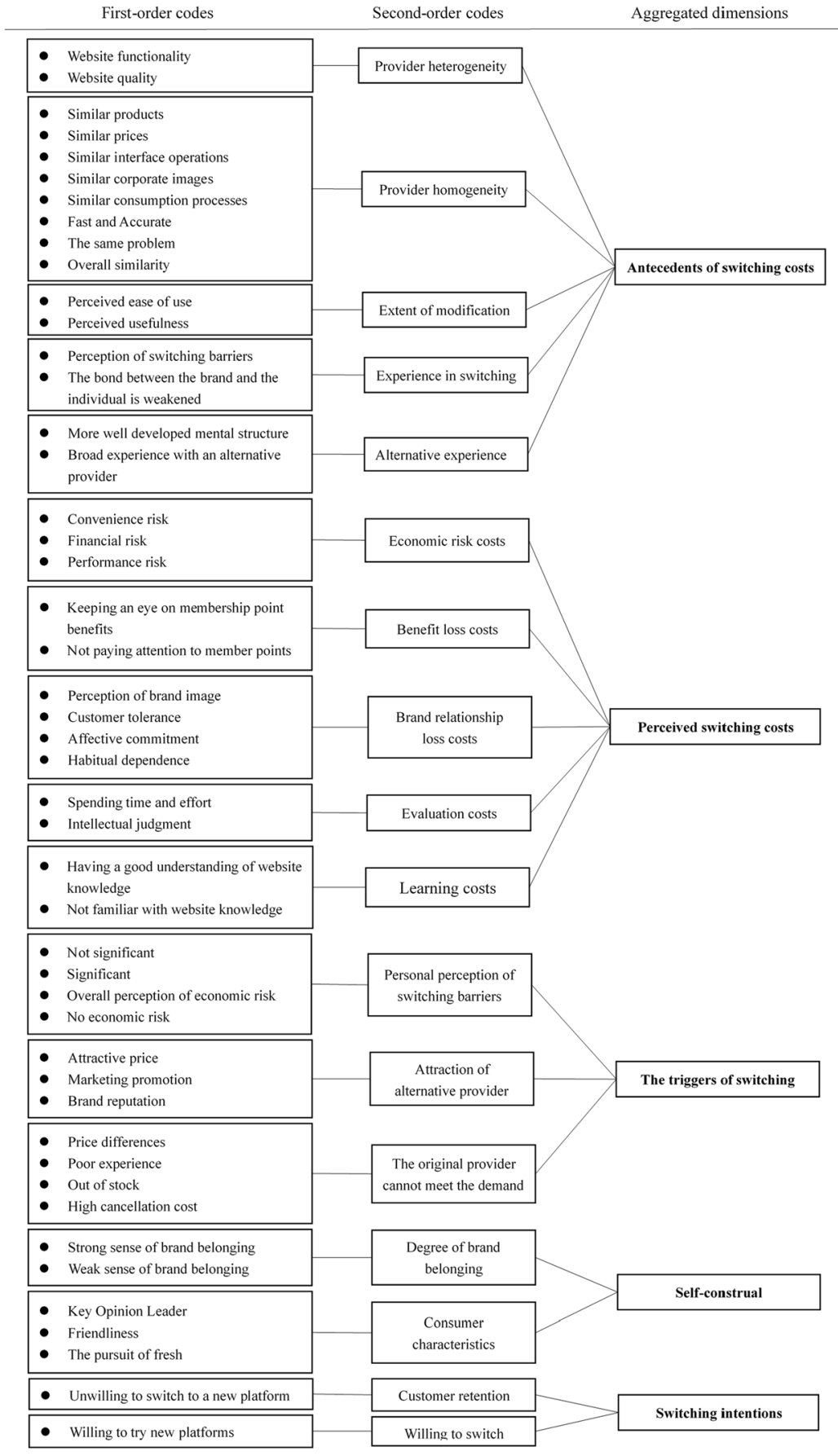

Fig. 3 Data analysis framework for customer-perceived switching costs 


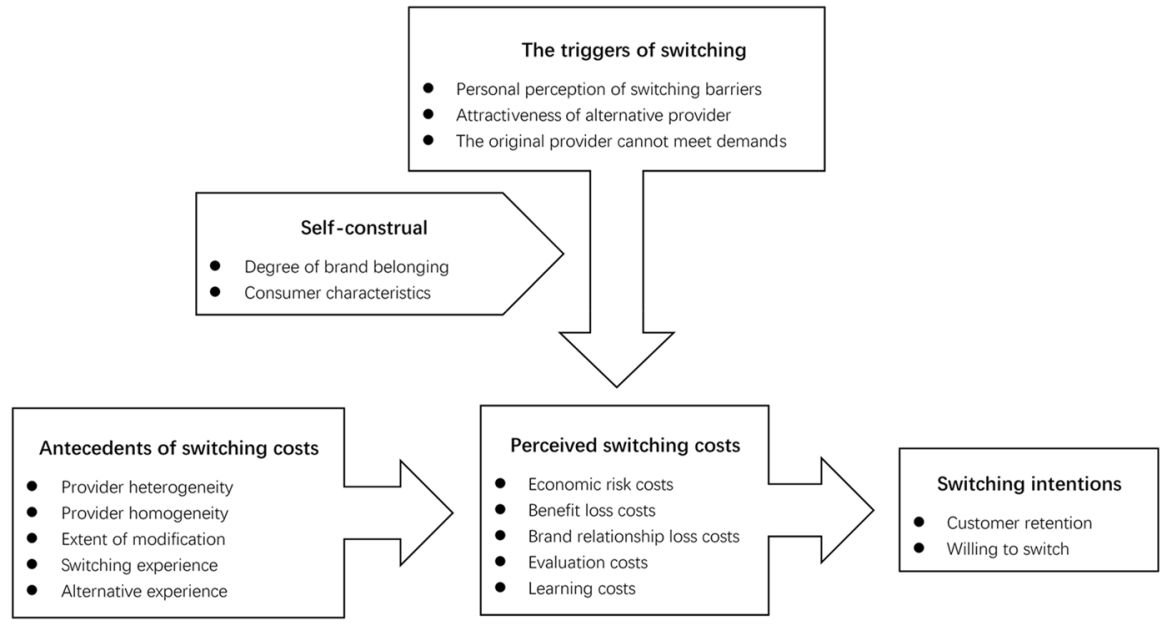

Fig. 4 Causal model of customer-perceived switching costs

The provider can considerately satisfy my need for a "home". They are just like family and give me safety. (Interviewee No. 2)

Due to different cultural contexts and operational habits, providers also show differences in platform interface designs and booking procedures, leading to provider heterogeneity, which causes an increase in customers' learning costs. For instance, interviewee No. 4 mentioned that the Airbnb booking platform, introduced from abroad, is different from the platform that he or she used. Such provider heterogeneity leads to an increase in the time and energy spent to switch to a new platform.

Airbnb was actually introduced from abroad, and it is quite different from the one we use. (Interviewee No. 4)

Because of the cooperation between providers and payment platforms, the booking procedures are simplified, and the payments are secured, resulting in a unique payment advantage that increases customers' economic risk costs for switching to an alternative provider. To protect their personal information and privacy, customers are inclined to choose their original booking platform.

Provider homogeneity Provider homogeneity has two effects. On the one hand, customers will suffer less from the influence of brand relationships if they feel that there are no major differences between providers, causing a reduction in brand relationship loss costs. On the other hand, provider homogeneity also becomes a switching barrier to customers who are familiar with their original provider that is, if they are the same, why switch? Such familiarity and habits help raise customers' brand relationship loss costs.

Extent of modification Customers' extent of modification comes from their perceived usefulness and perceived ease of use with regard to providers' products and services. Booking platforms that are easy to operate and have centralized functions can help reduce the convenience risk. Additionally, good experience 
with customer service will help win customers' trust in the brand. As a result, customers' extent of modification and changes in customer service will result in a brand relationship loss during a switch to other platforms, generating switching costs.

Alternative experience Customers' alternative experience consists of expertise and mental structures. For customers who master network techniques and have welldeveloped mental structures, their greater alternative experience helps reduce the relationship switching costs. Interviewee No. 1 had experience using similar apps; thus, he or she was not influenced even though one app was different from that which he or she had used.

Experience of switching Experience of switching involves two facets: the relationship between brands and individuals and perceived switching barriers. Switches will happen when customers and providers are emotionally separable and when provider homogeneity is high and customers' perceived entry barrier is low (Interviewee No. 9).

Now, the interfaces of some online hotel booking platforms are quite similar, so learning to use them is not a big deal to me. And such an amount of time for learning is not a big loss to me if I really need it. (Interviewee No. 9)

Perceived switching costs The perceived switching costs of online hotel booking platforms include brand relationship loss costs, economic risk costs, learning costs, evaluation costs and benefit loss costs. Data analysis shows that regarding brand relationship loss costs, perceived brand image, habitual dependence, affective commitment and customer tolerance can help produce barriers preventing customers from switching to alternative providers. This finding is consistent with the study of Tsai et al. (2011) that brand trust in virtual communities and brands is the decisive factor for customers' intentions to purchase.

Additionally, there are still learning costs among some customers even though providers offer more humanized websites, easier web navigation and more convenient interaction modes (Bilgihan and Bujisic 2015). If there is obvious heterogeneity in website features, customers tend to stay with their original provider to avoid learning new operation methods, refusing to get used to different webpages and changing their previous habits. Customers who are familiar with network techniques can easily switch among different providers without any learning costs. Nevertheless, these customers still must provide their personal information for registration when they switch to new providers, which inevitably poses more risks regarding personal information. Therefore, economic risk costs help retain customers.

Self-construal The purchases that people make are partly explained by the "ego" concept, which shapes their own individual characteristics. Customers construct their self-identities and express their own characteristics through a brand that fits their image (Escalas and Bettman 2003). From the perspective of inner psychological mechanisms, self-construal is a problem-solving strategy. However, different cultural contexts can influence customers' self-construal (Escalas and Bettman 2005) such as the aforementioned attitudes towards Airbnb due to cultural differences. Additionally, if stimuli appear, customers are more inclined to switch when their individual characteristics and their sense of belonging to a brand are weak. For 
instance, interviewee No. 10 thought that the relationship between him or her and his or her provider is normal. The choice of platform makes no difference.

Triggers and switching intentions The data analysis of triggers and switching intentions found that the attractiveness of alternative providers (e.g., marketing, discounts, word-of-mouth) can stimulate customers to switch. If other platforms show greater attractiveness in terms of their prices and products, customers will be more willing to try new platforms. If the current provider's products or services do not meet customers' demands (e.g., poor experience, higher prices, no booking services available for favourite hotels), this failure to meet demands can stimulate the customers to switch.

\subsubsection{Word frequency analysis}

In this study, word frequency analysis was conducted on the interview materials. Invalid words such as "no" and "one" were removed as appropriate, and we formed the word cloud containing the top 100 words most frequently used in the interview materials, as depicted in Fig. 5.

In the interviews, "use" was the word that was most frequently mentioned by the 10 interviewees. It was mentioned 116 times, indicating that hotel booking platform customers perceived switching costs mainly during the usage process.

Moreover, the words most frequently mentioned by the interviewees can be grouped into different conversion cost types and listed in order of frequency: the first category refers to brand relationship loss costs and includes "familiar", "habits", "reply", "call", "brand", "satisfaction", and "speed". The second category is related to procedural evaluation costs and includes "compare", "need", and "information". The third category is related to learning costs and includes "registration", "operation", "learning", "interface", "trouble", "adaptation", "app", and "download". The fourth category is related to economic risk costs and includes "time", "cost", "problem", "payment", and "risk". The fifth category concerns revenue loss costs and includes "credits" and "member".

Fig. 5 Word cloud

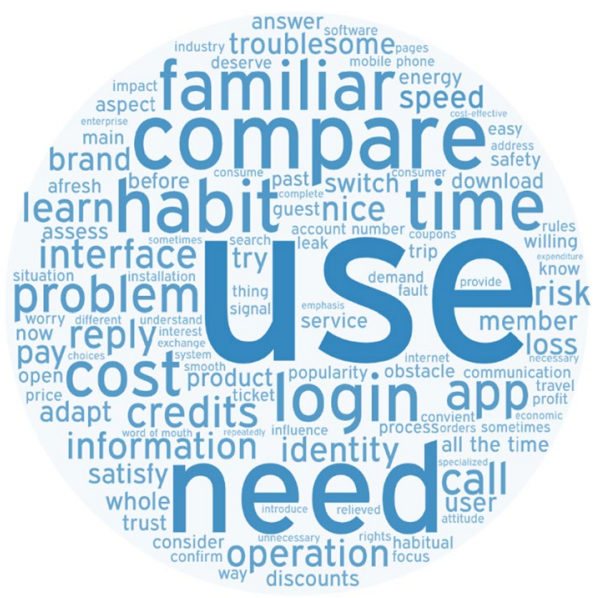


Meanwhile, among the words frequently mentioned by the interviewees, there are two categories of words that warrant attention. One category consists of words such as "present", "past", "loss" and "gain", indicating that customers will compare profits and losses before and after switching behaviour when evaluating the switching cost. The other category consists of words such as "overall" and "whole", reflecting the interviewees' tendency to comprehensively consider a variety of costs when evaluating PSCs.

\section{Discussion and conclusions}

\subsection{Discussion of main findings}

This research provides insights into the interrelationships among different types of antecedents and different facets of switching costs within the context of online hotel booking.

First, our empirical results reveal that relational switching costs are perceived as being significantly associated with customers' intentions to continue using a certain online booking platform. The subsequent qualitative analysis results supplement and explain this quantitative result. The qualitative study found that provider homogeneity, the extent of modification, and alternative experience could affect the customer's perception of brand relationship lost cost, which in turn influences whether customers will make switching decisions. In addition, it was found that perceived brand image, habitual dependence, affective commitment and customer tolerance in the brand relationship lost played a role in preventing customers from turning to other providers.

Second, the qualitative research constructs a causal model of customer switching costs within the context of online hotel booking. The antecedents of perceived switching cost such as provider heterogeneity, provider homogeneity, extent of modification, switching experience and alternative experience will affect PSCs. Only when the triggers (e.g., personal perception of switching barriers, the original provider cannot meet demands and the attractiveness of an alternative provider) are activated will the customer carefully perceive and evaluate switching cost and then decide whether to switch. In addition, there are also differences in the influence of customers' self-construal on the relationship between triggers and PSCs.

Third, the qualitative analysis found a high extent of modification (e.g., easy operation or centralized functions perceived by customers) with regard to customers' current providers can help reduce economic risks. Meanwhile, the service and help that customers obtain from provider service also help establish a bond between customers and the brand, thus raising brand relationship loss costs, which conforms to the findings of our quantitative research.

Fourth, our qualitative research also reveals the influence of switching experience on switching costs, indicating that switching experience has an influence. Once again, this finding indicates that our use of switching experience as a control variable in our quantitative research is rational and scientific. It also shows the consistency and complementarity between our quantitative and qualitative research. 
Fifth, this research found that for consumers who are familiar with network technology, there is no learning cost. However, for other consumers, learning cost exists, and it will have both a positive and negative impact on switching intentions in the online hotel booking context.

\subsection{Theoretical contributions}

Based on mixed method, this study shows some major contributions from different aspects:

Firstly, quantitative study achieves some breakthroughs on classic PSCs model. Compared to existing research, quantitative study shows the differences of PSCs in online hospitality booking. This study finds that relationship loss costs contribute the most to the formation of the PSC construct in the context of online hotel bookings.

Secondly, the most important theoretical implication of this research is from qualitative research, which demonstrates that the conceptualization of PSCs as a multi-dimensional construct in the hospitality can significantly improve our theoretical framing of how and why switching costs alter customers' choice of online hotel booking services. The higher-order formative conceptualization of the PSC construct reveals a hierarchy of importance among the facets in forming the higherorder construct (Barroso and Picón 2012).

Third, this finding also reflects the special attributes of the PSC concept in different industries. Burnham et al. (2003) found that consumers' perceptions of switching costs may be increased by increasing provider heterogeneity. In this research, the qualitative analysis shows that provider homogeneity is one of the facets of the antecedents of switching costs. On the one hand, provider homogeneity can reduce customers' learning costs, enabling them to switch easily. On the other hand, high provider homogeneity makes customers feel that there are no remarkable differences between their original provider and alternative providers; thus, their switches are hindered by brand identity, which reduces the brand relationship loss costs. Since heterogeneity and homogeneity are two opposite definitions of the differences between providers, the influence of provider homogeneity on switching costs indirectly supports the finding of the quantitative analysis, i.e., the effect of provider heterogeneity on switching costs.

Fourthly, this research indicates that mechanism of PSCs is complex. Integration of two different method helps identify that brand relationship loss costs significantly influence customers' intentions to continue using a certain online booking platform. This finding may run counter to people's understanding of the dimensions of switching costs in the context of contactless online shopping services. Customers' perceived image cognition, habitual dependence, affective commitment and even tolerance all indicate that online customers trust their original website for longterm use and have customer loyalty. That is, trust has become an important factor in attracting, conducting transactions with and retaining customers in an online context (El-Said 2020; Shiau and Luo 2012). Therefore, this finding provides significant 
insight into the future business perspective of online hotel booking platforms based on social and psychological factors.

\subsection{Practical implications}

This research has two practical implications regarding (1) how online hotel booking service providers can better manage switching costs and (2) how they can exert effort more efficiently to gain customer retention.

As identified by our research, technology has simplified and optimized the whole customer journey when booking hotels online, thus reducing the amount of procedural and financial switching costs and placing a much heavier emphasis on relational switching costs. To better manage switching costs, online hotel booking services should reflect on their strategies for cultivating a strong brand-customer relationship. The stronger the relationship is, the higher the switching barrier.

Based on our qualitative findings, better management in this regard involves both service-related and technology-related efforts. Online booking platforms need to provide a consistent level of service quality, especially to avoid service failures. They should also incentivize and reward customers for investing in the brand-customer relationship, for example, by completing their profiles, updating their preferences, and simplifying their customer journeys. Online booking platforms can also benchmark the technology to keep customers happy in regard to their user experiences. The satisfaction with the service and technology that customers have gained will then reinforce their positive attitude towards the brand-customer relationship. Consequently, customers will continue with the service provider as the relational switching costs become more expensive.

However, this does not mean that other switching costs are not important. For many small and medium-sized online hotel booking platforms that have a much smaller customer base, we recommend that they identify which facets of switching costs have hindered customers from using their services. For example, they can check whether they have provided a hassle-free online booking procedure, whether they have provided competitive hotel prices and ranges, and whether they have established their unique strengths in cultivating a strong brand-customer relationship.

\section{Limitations and suggestions for future study}

The first limitation of this research is the exclusion of factors that might mitigate the impact of switching costs on customers' intentions to continue using a certain online booking platform. For instance, some research has found that customer satisfaction with the service can be an important factor in mitigating the effect of relational switching costs (Blut et al. 2015). It has been proposed that if a customer is sufficiently satisfied with his/her current service, he or she will be likely to stay with the current service provider even though the switching costs are very low. Thus, future research can include "lock-in factors" such as satisfaction, commitment, and habit to further evaluate the mitigating effect of these factors on PSCs. 
To the best of our knowledge, our study is among the first to advocate the use of a multi-dimensional conceptualization of PSCs in hospitality and tourism research. However, as the second limitation of this research, we tested only the direct impact of PSCs on customers' intentions to continue using a certain online booking platform. Some research in other service industries, such as the banking industry, has tested the sub-dimensions of PSC as both antecedents and moderators, and mixed results have been found (Chebat et al. 2011). When other factors are included, such as satisfaction, service failure and emotions (Nikbin et al. 2015), it is worth exploring the interaction effect between PSCs and these factors. Therefore, future work can draw on other theoretical perspectives and conduct empirical tests on the moderating role of PSCs. Moreover, some classic theories could give new ways for PSCs study. For example, social network explained the interests between different organizations (or individuals), which also shows PSCs are widespread (Valeri and Baggio 2020a; b, c).

As the third limitation of this research, although the representativity of the sample in the quantitative phase of this research was fairly good, the generalizability of the findings still must be treated with caution. Since the qualitative study participants were all from first-tier cities and many respondents in the quantitative study were also from first- and second-tier cities, the findings should not be generalized to cover the situation of other types of cities in China. Some statistics have shown a trend in which third-tier and lower-tier cities or less populated and less industrialized cities in China have become a major growth driver in online hotel booking; for example, in June 2018, such cities contributed 50\% of all online hotel bookings (Mariano 2018). Therefore, future research can recruit participants from such cities and compare the differences. It would be interesting to determine whether customers in lower-tier cities are more sensitive to certain types of PSCs than those in highertier cities.

\section{Appendix 1: Construct scale items}

\begin{tabular}{lll}
\hline Construct & Items & Adapted from \\
\hline $\begin{array}{l}\text { Market characteristics: provider } \\
\text { heterogeneity (PH) }\end{array}$ & Among online hotel booking service & Burnham et al. (2003) \\
& providers, to what extent do you & \\
agree with the following state- & \\
ments? (7-point Likert scale) & \\
PH1: The quality of online services & \\
varies greatly among different & service providers \\
PH2: I could be using a competing & service provider and not notice \\
much difference (r) & PH3: Different service providers in \\
this industry offer very different & \\
features & \\
\hline
\end{tabular}




\begin{tabular}{|c|c|c|}
\hline Construct & Items & Adapted from \\
\hline $\begin{array}{l}\text { Domain expertise: alternative experi- } \\
\text { ence (AE) }\end{array}$ & $\begin{array}{l}\text { Among online hotel booking service } \\
\text { providers, to what extent do you } \\
\text { agree with the following state- } \\
\text { ments? (7-point Likert scale) } \\
\text { AE1: I have tried the services offered } \\
\text { by other service providers } \\
\text { AE2: I am familiar with the quality } \\
\text { of service that other service provid- } \\
\text { ers offer }\end{array}$ & \\
\hline $\begin{array}{l}\text { Consumer investments: extent of } \\
\text { modification (EOM) }\end{array}$ & $\begin{array}{l}\text { Think of the website you have mostly } \\
\text { used for online hotel booking. To } \\
\text { what extent do you agree with the } \\
\text { following statements? (7-point } \\
\text { Likert scale) } \\
\text { EOM1: I have put effort into "setting } \\
\text { up" my account on the website to } \\
\text { use it in a personalized way } \\
\text { EOM2: I have invested time and } \\
\text { effort to accumulate benefits from } \\
\text { using the website } \\
\text { EOM3: I have adapted to the com- } \\
\text { munication service so that the } \\
\text { interaction between me and the } \\
\text { website is smooth }\end{array}$ & Burnham et al. (2003) \\
\hline $\begin{array}{l}\text { Procedural switching costs: economic } \\
\text { risk costs (ERC) }\end{array}$ & $\begin{array}{l}\text { Think of the online channel you have } \\
\text { mostly used for online hotel book- } \\
\text { ing. To what extent do you agree } \\
\text { with the following statements? } \\
\text { (7-point Likert scale) } \\
\text { ERC1: Switching to a new service } \\
\text { provider will probably involve hid- } \\
\text { den costs/charges } \\
\text { ERC2: I am likely to end up with a } \\
\text { bad deal financially if I switch to a } \\
\text { new service provider } \\
\text { ERC3: Switching to a new service } \\
\text { provider will result in some unex- } \\
\text { pected hassles }\end{array}$ & Barroso and Picón (2012) \\
\hline $\begin{array}{l}\text { Procedural switching costs: evalua- } \\
\text { tion costs (EC) }\end{array}$ & $\begin{array}{l}\text { EC1: I cannot afford the time to get } \\
\text { the information to fully evaluate } \\
\text { other service providers } \\
\text { EC2: I think that it takes too much } \\
\text { time/effort to get the information } \\
\text { needed to feel comfortable evaluat- } \\
\text { ing a new service provider }\end{array}$ & Barroso and Picón (2012) \\
\hline
\end{tabular}




\begin{tabular}{|c|c|c|}
\hline Construct & Items & Adapted from \\
\hline $\begin{array}{l}\text { Financial switching costs: benefit } \\
\text { loss costs (BLC) }\end{array}$ & $\begin{array}{l}\text { BLC1: Switching to a new service } \\
\text { provider would mean losing or } \\
\text { replacing points, credits, services, } \\
\text { and so on that I have accumulated } \\
\text { with my current service provider } \\
\text { BLC2: I would lose a lot of credits, } \\
\text { accumulated points, services I } \\
\text { have already paid for, and so on if I } \\
\text { switched to a new service provider } \\
\text { BLC3: I will lose the benefits of } \\
\text { being a long-term customer if I } \\
\text { leave my current service provider }\end{array}$ & Barroso and Picón (2012) \\
\hline $\begin{array}{l}\text { Relational switching costs: brand } \\
\text { relationship loss costs (BRLC) }\end{array}$ & $\begin{array}{l}\text { BRLC1: I like the public image } \\
\text { my current online hotel booking } \\
\text { platform has } \\
\text { BRLC2: I generally care about the } \\
\text { brand/company name of the online } \\
\text { hotel booking platform }\end{array}$ & Burnham et al. (2003) \\
\hline $\begin{array}{l}\text { Intentions to continue with the cur- } \\
\text { rent provider (ITC) }\end{array}$ & $\begin{array}{l}\text { ITC1: What is the chance that you } \\
\text { will continue with your current } \\
\text { online booking service provider for } \\
\text { the next year? } \\
\text { ITC2: In other words, how likely } \\
\text { are you to switch to another online } \\
\text { booking service provider over the } \\
\text { next year? (very unlikely ... very } \\
\text { likely) (r) }\end{array}$ & Burnham et al. (2003) \\
\hline
\end{tabular}

\section{Appendix 2: Distribution of respondent characteristics.}

\begin{tabular}{|c|c|c|c|c|c|c|}
\hline Gender & $\mathrm{N}$ & & $\%$ & Age & $\mathrm{N}$ & $\%$ \\
\hline Male & 169 & & 45.92 & $18-24$ & 108 & 29.35 \\
\hline \multirow[t]{3}{*}{ Female } & 199 & & 54.08 & $25-34$ & 163 & 44.29 \\
\hline & & & & $35-44$ & 86 & 23.37 \\
\hline & & & & $45-54$ & 11 & 2.99 \\
\hline \multicolumn{2}{|l|}{ Education } & $\mathrm{N}$ & $\%$ & Annual Income & $\mathrm{N}$ & $\%$ \\
\hline \multicolumn{2}{|l|}{ High school and lower } & 19 & 5.16 & RMB $60 \mathrm{~K}$ or less & 53 & 14.40 \\
\hline \multicolumn{2}{|l|}{ Bachelor's degree } & 256 & 69.57 & RMB $60 \mathrm{~K}-100 \mathrm{~K}$ & 89 & 24.18 \\
\hline \multicolumn{2}{|l|}{ Master's degree } & 78 & 21.20 & RMB $100 \mathrm{~K}-200 \mathrm{~K}$ & 124 & 33.70 \\
\hline \multirow{2}{*}{\multicolumn{2}{|c|}{$\mathrm{PhD}$ degree }} & 15 & 4.08 & RMB $200 \mathrm{~K}-300 \mathrm{~K}$ & 67 & 18.21 \\
\hline & & & & RMB $300 \mathrm{~K}$ or more & 35 & 9.51 \\
\hline \multicolumn{2}{|l|}{ Length of membership } & $\mathrm{N}$ & $\%$ & Frequency of usage & $\mathrm{N}$ & $\%$ \\
\hline \multicolumn{2}{|l|}{ Less than 3 months } & 13 & 3.53 & Rare & 15 & 4.08 \\
\hline \multicolumn{2}{|l|}{$3-6$ months } & 22 & 5.98 & Sometimes & 73 & 19.84 \\
\hline
\end{tabular}




\begin{tabular}{llllll}
\hline Length of membership & $\mathrm{N}$ & $\%$ & Frequency of usage & $\mathrm{N}$ & $\%$ \\
\hline 6 months-1 year & 41 & 11.14 & Fairly frequent & 156 & 42.39 \\
1-2 years & 101 & 27.45 & Frequent & 81 & 22.01 \\
Over 2 years & 191 & 51.90 & Extremely frequent & 43 & 11.68 \\
\hline
\end{tabular}

\section{Appendix 3: HTMT matrix}

\begin{tabular}{|c|c|c|c|c|c|c|c|c|}
\hline & $\begin{array}{l}\text { Alterna- } \\
\text { tive expe- } \\
\text { rience }\end{array}$ & $\begin{array}{l}\text { Benefit } \\
\text { loss costs }\end{array}$ & $\begin{array}{l}\text { Brand } \\
\text { relation- } \\
\text { ship loss } \\
\text { costs }\end{array}$ & $\begin{array}{l}\text { Eco- } \\
\text { nomic } \\
\text { risk } \\
\text { costs }\end{array}$ & $\begin{array}{l}\text { Evalu- } \\
\text { ation } \\
\text { costs }\end{array}$ & $\begin{array}{l}\text { Extent of } \\
\text { modifi- } \\
\text { cation }\end{array}$ & $\begin{array}{l}\text { Inten- } \\
\text { tions to } \\
\text { continue }\end{array}$ & $\begin{array}{l}\text { Provider } \\
\text { heteroge- } \\
\text { neity }\end{array}$ \\
\hline $\begin{array}{l}\text { Alterna- } \\
\text { tive } \\
\text { Experi- } \\
\text { ence }\end{array}$ & - & & & & & & & \\
\hline $\begin{array}{l}\text { Ben- } \\
\text { efit loss } \\
\text { costs }\end{array}$ & 0.303 & - & & & & & & \\
\hline $\begin{array}{l}\text { brand } \\
\text { rela- } \\
\text { tionship } \\
\text { loss } \\
\text { costs }\end{array}$ & 0.551 & 0.423 & - & & & & & \\
\hline $\begin{array}{l}\text { Eco- } \\
\text { nomic } \\
\text { risk } \\
\text { costs }\end{array}$ & 0.448 & 0.804 & 0.484 & - & & & & \\
\hline $\begin{array}{c}\text { evalu- } \\
\text { ation } \\
\text { costs }\end{array}$ & 0.301 & 0.308 & 0.153 & 0.314 & - & & & \\
\hline $\begin{array}{l}\text { Extent of } \\
\text { modifi- } \\
\text { cation }\end{array}$ & 0.719 & 0.480 & 0.794 & 0.560 & 0.259 & - & & \\
\hline $\begin{array}{l}\text { Inten- } \\
\text { tions to } \\
\text { con- } \\
\text { tinue }\end{array}$ & 0.337 & 0.285 & 0.826 & 0.218 & 0.030 & 0.536 & - & \\
\hline $\begin{array}{l}\text { Provider } \\
\text { hetero- } \\
\text { geneity }\end{array}$ & 0.729 & 0.368 & 0.463 & 0.717 & 0.045 & 0.525 & 0.280 & - \\
\hline
\end{tabular}




\section{Appendix 4: Cross-loadings}

\begin{tabular}{lcllllllr}
\hline & $\begin{array}{l}\text { Alterna- } \\
\text { tive expe- } \\
\text { rience }\end{array}$ & $\begin{array}{l}\text { Benefit } \\
\text { loss costs }\end{array}$ & $\begin{array}{l}\text { Brand } \\
\text { relation- } \\
\text { ship loss } \\
\text { costs }\end{array}$ & $\begin{array}{l}\text { Eco- } \\
\text { nomic } \\
\text { risk } \\
\text { costs }\end{array}$ & $\begin{array}{l}\text { Evalu- } \\
\text { ation } \\
\text { costs }\end{array}$ & $\begin{array}{l}\text { Extent of } \\
\text { modifi- } \\
\text { cation }\end{array}$ & $\begin{array}{l}\text { Inten- } \\
\text { tions to } \\
\text { continue }\end{array}$ & $\begin{array}{l}\text { Provider } \\
\text { heteroge- } \\
\text { neity }\end{array}$ \\
\hline AE1 & 0.701 & 0.153 & 0.284 & 0.225 & -0.104 & 0.314 & 0.167 & 0.332 \\
AE2 & 0.953 & 0.215 & 0.302 & 0.254 & -0.241 & 0.473 & 0.230 & 0.430 \\
BLC1 & 0.238 & 0.912 & 0.276 & 0.490 & 0.214 & 0.257 & 0.209 & 0.235 \\
BLC2 & 0.179 & 0.846 & 0.258 & 0.452 & 0.192 & 0.290 & 0.185 & 0.203 \\
BLC3 & 0.169 & 0.883 & 0.209 & 0.487 & 0.209 & 0.346 & 0.171 & 0.206 \\
BrandLC1 & 0.264 & 0.217 & 0.777 & 0.197 & 0.073 & 0.353 & 0.546 & 0.214 \\
BrandLC2 & 0.262 & 0.208 & 0.733 & 0.226 & 0.077 & 0.370 & 0.471 & 0.182 \\
EC1 & -0.162 & 0.190 & 0.099 & 0.212 & 0.856 & -0.152 & -0.004 & -0.008 \\
EC2 & -0.200 & 0.223 & 0.115 & 0.177 & 0.917 & -0.144 & 0.021 & -0.061 \\
EC3 & -0.195 & 0.186 & 0.037 & 0.141 & 0.798 & -0.161 & 0.042 & -0.002 \\
EOM1 & 0.398 & 0.316 & 0.468 & 0.285 & -0.058 & 0.866 & 0.326 & 0.253 \\
EOM2 & 0.369 & 0.271 & 0.322 & 0.279 & -0.220 & 0.739 & 0.193 & 0.240 \\
EOM3 & 0.381 & 0.217 & 0.343 & 0.251 & -0.159 & 0.782 & 0.348 & 0.261 \\
ERC1 & 0.253 & 0.430 & 0.231 & 0.830 & 0.153 & 0.292 & 0.126 & 0.362 \\
ERC2 & 0.192 & 0.406 & 0.198 & 0.720 & 0.164 & 0.220 & 0.138 & 0.283 \\
ERC3 & 0.206 & 0.405 & 0.210 & 0.736 & 0.158 & 0.266 & 0.061 & 0.294 \\
ITC1 & 0.291 & 0.230 & 0.649 & 0.145 & -0.015 & 0.389 & 0.981 & 0.169 \\
ITC2 & 0.085 & 0.121 & 0.495 & 0.092 & 0.072 & 0.211 & 0.709 & 0.138 \\
PH1 & 0.381 & 0.171 & 0.185 & 0.305 & -0.011 & 0.156 & 0.117 & 0.720 \\
PH3 & 0.313 & 0.196 & 0.210 & 0.315 & -0.032 & 0.312 & 0.152 & 0.784 \\
\hline
\end{tabular}

\section{Appendix 5: Full collinearity VIFs}

\begin{tabular}{lllllllll}
\hline & $\begin{array}{l}\text { Alterna- } \\
\text { tive expe- } \\
\text { rience }\end{array}$ & $\begin{array}{l}\text { Benefit } \\
\text { loss costs }\end{array}$ & $\begin{array}{l}\text { Brand } \\
\text { relation- } \\
\text { ship loss } \\
\text { costs }\end{array}$ & $\begin{array}{l}\text { Eco- } \\
\text { nomic } \\
\text { risk costs }\end{array}$ & $\begin{array}{l}\text { Evalua- } \\
\text { tion costs }\end{array}$ & $\begin{array}{l}\text { Extent of } \\
\text { modifica- } \\
\text { tion }\end{array}$ & $\begin{array}{l}\text { Inten- } \\
\text { tions to } \\
\text { Continue }\end{array}$ & $\begin{array}{l}\text { Provider } \\
\text { heteroge- } \\
\text { neity }\end{array}$ \\
\hline $\begin{array}{l}\text { Alterna- } \\
\text { tive }\end{array}$ & - & 1.600 & 1.575 & 1.599 & 1.524 & 1.51 & 1.602 & 1.435 \\
$\begin{array}{l}\text { Experi- } \\
\text { ence }\end{array}$ & & & & & & & & \\
$\begin{array}{c}\text { Ben- } \\
\text { efit loss } \\
\text { costs }\end{array}$ & 1.550 & - & 1.553 & 1.297 & 1.488 & 1.506 & 1.545 & 1.553 \\
\hline
\end{tabular}




\begin{tabular}{|c|c|c|c|c|c|c|c|c|}
\hline & $\begin{array}{l}\text { Alterna- } \\
\text { tive expe- } \\
\text { rience }\end{array}$ & $\begin{array}{l}\text { Benefit } \\
\text { loss costs }\end{array}$ & $\begin{array}{l}\text { Brand } \\
\text { relation- } \\
\text { ship loss } \\
\text { costs }\end{array}$ & $\begin{array}{l}\text { Eco- } \\
\text { nomic } \\
\text { risk costs }\end{array}$ & $\begin{array}{l}\text { Evalua- } \\
\text { tion costs }\end{array}$ & $\begin{array}{l}\text { Extent of } \\
\text { modifica- } \\
\text { tion }\end{array}$ & $\begin{array}{l}\text { Inten- } \\
\text { tions to } \\
\text { Continue }\end{array}$ & $\begin{array}{l}\text { Provider } \\
\text { heteroge- } \\
\text { neity }\end{array}$ \\
\hline $\begin{array}{l}\text { Brand } \\
\text { rela- } \\
\text { tionship } \\
\text { loss } \\
\text { costs }\end{array}$ & 2.193 & 2.232 & - & 2.223 & 2.155 & 2.089 & 1.420 & 2.23 \\
\hline $\begin{array}{l}\text { Eco- } \\
\text { nomic } \\
\text { risk } \\
\text { costs }\end{array}$ & 1.698 & 1.422 & 1.695 & - & 1.651 & 1.673 & 1.687 & 1.57 \\
\hline $\begin{array}{r}\text { Evalu- } \\
\text { ation } \\
\text { costs }\end{array}$ & 1.224 & 1.234 & 1.243 & 1.248 & - & 1.203 & 1.285 & 1.287 \\
\hline $\begin{array}{l}\text { Extent of } \\
\text { modifi- } \\
\text { cation }\end{array}$ & 1.620 & 1.667 & 1.609 & 1.689 & 1.607 & - & 1.714 & 1.719 \\
\hline $\begin{array}{l}\text { Intentions } \\
\text { to con- } \\
\text { tinue }\end{array}$ & 1.866 & 1.857 & 1.188 & 1.849 & 1.864 & 1.86 & - & 1.866 \\
\hline $\begin{array}{l}\text { Provider } \\
\text { hetero- } \\
\text { geneity }\end{array}$ & 1.280 & 1.429 & 1.428 & 1.318 & 1.429 & 1.429 & 1.429 & - \\
\hline
\end{tabular}

Aknowledgemants We appreciate Dr. Stella Tian and all reviewers for their valuable comments.

Funding Funding was provided by National Social Science Foundation of China (Project No: 18BGL150).

\section{Declaration}

Conflict of interest The authors declare no conflicts of interest.

\section{References}

Anderson JC, Gerbing DW (1988) Structural equation modeling in practice: a review and recommended two-step approach. Psychol Bull 103(3):411-411

Arasil Ö, Aydin S, Özer G (2005) Customer loyalty and the effect of switching costs as a moderator variable: a case in the Turkish mobile phone market. Mark Intell Plan 23(1):89-103

Armstrong JS, Overton TS (1977) Estimating nonresponse bias in mail surveys. J Mark Res 14(3):396-402

Aydin S, Özer G (2005) The analysis of antecedents of customer loyalty in the Turkish mobile telecommunication market. Eur J Mark 39:910-925

Barclay D, Higgins C, Thompson R (1995) The partial least square (PLS) approach to casual modeling: personal computer adoption and use as an illustration. Technology 2(2):285-309

Barroso C, Picón A (2012) Multi-dimensional analysis of perceived switching costs. Ind Mark Manag 41(3):531-543

Bilgihan A, Bujisic M (2015) The effect of website features in online relationship marketing: a case of online hotel booking. Electron Commer Res Appl 14(4):222-232 
Bitner MJ (1995) Building service relationships: it's all about promises. J Acad Mark Sci 23(4):246-251

Blau PM (1964) Exchange and power in social life. Wiley, New York

Blut M, Frennea CM, Mittal V, Mothersbaugh DL (2015) How procedural, financial and relational switching costs affect customer satisfaction, repurchase intentions, and repurchase behavior: a metaanalysis. Int J Res Mark 32(2):226-229

Buhalis D, Law R (2008) Progress in information technology and tourism management: 20 years on and 10 years after the internet— the state of etourism research. Tour Manag 29(4):609-623

Burnham TA, Frels JK, Mahajan V (2003) Consumer switching costs: a typology, antecedents, and consequences. J Acad Mark Sci 31(2):109-126

Chang YW, Hsu PY, Lan YC (2019) Cooperation and competition between online travel agencies and hotels. Tour Manag 71:187-196

Charmaz K (2006) Constructing grounded theory: a practical guide through qualitative analysis. SAGE, London

Chebat J-C, Davidow M, Borges A (2011) More on the role of switching costs in service markets: a research note. J Bus Res 64(8):823-829

Chin WW (1998) The partial least squares approach to structural equation modeling. In: Marcoulides GA (ed) Modern methods for business research. Lawrence Erlbaum Associates, Mahwah

Charmaz K, Belgrave LL (2019) Thinking about data with grounded theory. Qualitative Inquiry 25(8):743-753. https://doi.org/10.1177/1077800418809455

Corbin J, Strauss A (1990) Grounded theory research: procedures, canons, and evaluative criteria. Qual Sociol 19(6):418-427

Creswell JW, Clark VLP (2006) Designing and conducting mixed methods research. Sage Publications, Thousand Oaks

Crnojevac IH, Gugić J, Karlovčan S (2010) eTourism: a comparison of online and offline bookings and the importance of hotel attributes. J Inf Organ Sci 34(1):41-54

David M (2014) Online panels China: QQ survey, So Jump and Diaochapai. http://daxueconsulting.com/ online-panels-china/. Accessed 28 May 2014

Edward M, Sahadev S (2011) Role of switching costs in the service quality, perceived value, customer satisfaction and customer retention linkage. Asia Pac J Mark Logist 23(3):327-345

El-Said OA (2020) Impact of online reviews on hotel booking intention: the moderating role of brand image, star category, and price. Tour Manag Perspect 33:100604

Escalas JE, Bettman JR (2003) You are what they eat: the influence of reference groups on consumers' connections to brands. J Consum Psychol 13(3):339-348

Escalas JE, Bettman JR (2005) Self-construal, reference groups, and brand meaning. J Consum Res 32(3):378-389

Feilzer MY (2010) Doing mixed methods research pragmatically: implications for the rediscovery of pragmatism as a research paradigm. J Mixed Methods Res 4(1):6-16

Fornell C (1992) A national customer satisfaction barometer: the Swedish experience. J Mark 56(1):6-21

Fornell C, Larcker DF (1981) Evaluating structural equation models with unobservable variables and measurement error. J Mark Res 18(1):39-50

Gellerstedt M, Arvemo T (2019) The impact of word of mouth when booking a hotel: could a good friend's opinion outweigh the online majority? Inf Technol Tour 21(3):289-311

Gu H, Ryan C (2010) Hongcun, china-residents' perceptions of the impacts of tourism on a rural community: a mixed methods approach. J China Tour Res 6(3):216-243

Guillet BD, Mattila A, Gao L (2019) The effects of choice set size and information filtering mechanisms on online hotel booking. Int J Hosp Manag 87:102379

Guiltinan JP (1989) A classification of switching costs with implications for relationship marketing. In: Paper presented at the AMA Educator's Conference on Marketing Theory and Practice, American Marketing Association, Chicago, IL

Hair JF, Black WC, Babin BJ, Anderson RE, Tatham RL (1998) Multivariate data analysis, 5th edn. Prentice Hall, Upper Saddle River

Han H, Back KJ, Kim YH (2011a) A multidimensional scale of switching barriers in the full-service restaurant industry. Cornell Hosp Q 52(1):54-63

Han H, Kim W, Hyun SS (2011b) Switching intention model development: role of service performances, customer satisfaction, and switching barriers in the hotel industry. Int J Hosp Manag 30(3):619-629

Hao F, Xiao Q, Chon K (2020) Covid-19 and china's hotel industry: impacts, a disaster management framework, and post-pandemic agenda—science direct. Int J Hosp Manag 90:102636 (In press) 
Heide J, Weiss A (1995) Vendor consideration and switching behaviour for buyers in high-technology markets. J Mark 59(3):30-44

Hofstede G (1984) Cultural dimensions in management and planning. Asia Pac J Manag 1(2):81-99

Jackson BB (1985) Winning and keeping industrial customers. Lexington Books, Lexington

Jennings S (2014) Winning the race for guest loyalty. https://www2.deloitte.com/content/dam/Deloitte/tr/ Documents/consumer-business/winning-the-race-hotel-loyalty-pov-final.pdf

Jennings S (2018) Travel and hospitality industry outlook. https:/www2.deloitte.com/content/dam/Deloi tte/us/Documents/consumer-business/us-cb-2018-travel-hospitality-industry-outlook.pdf

Jesus Lopez-Miguens M, Gonzalez Vazquez E (2017) An integral model of e-loyalty from the consumer's perspective. Comput Hum Behav 72(7):397-411

Johnson RB, Onwuegbuzie AJ (2004) A research paradigm whose time has come. Educ Researcher 33(7):14-26

Johnson RB, Onwuegbuzie AJ, Turner LA (2007) Toward a definition of mixed methods research. J Mixed Methods Res 1(2):112-133. https://doi.org/10.1177/1558689806298224

Jones T, Taylor S (2007) The conceptual domain of service loyalty: how many dimensions. J Serv Mark 21(1):36-51

Jones MA, Mothersbaugh DL, Beatty SE (2000) Switching barriers and repurchase intentions in services. J Retail 76(2):259-274

Kim I, Cho M (2014) The impact of brand relationship and attributions on passenger response to service failure. Asia Pac J Tour Res 19(12):1441-1462

Kim SS, Chun H, Lee H (2005) The effects of SARS on the Korean hotel industry and measures to overcome the crisis: a case study of six Korean five-star hotels. Asia Pac J Tour Res 10(4):369-377

Kim G, Shin B, Lee HG (2006) A study of factors that affect user intentions toward email service switching. Inf Manag 43(7):884-893

Klein LR (1998) Evaluating the potential of interactive media through a new lens: search versus experience goods. J Bus Res 41(3):195-203

Kock N (2015) Common method bias in PLS-SEM: a full collinearity assessment approach. Int J e-Collab 11(4):1-10

Kock N, Lynn GS (2012) Lateral collinearity and misleading results in variance-based SEM: an illustration and recommendations. J Assoc Inf Syst 13(7):546-580

Koo B, Curtis C, Ryan B (2020a) Examining the impact of artificial intelligence on hotel employees through job insecurity perspectives. Int J Hosp Manag 102763

Koo B, Yu J, Han H (2020b) The role of loyalty programs in boosting hotel guest loyalty: impact of switching barriers. Int J Hosp Manag 84:102328

Lam SY, Shankar V, Erramilli MK, Murthy B (2004) Customer value, satisfaction, loyalty, and switching costs: an illustration from a business-to-business service context. J Acad Mark Sci 32(3):293-311

Li H, Gan C (2015) Understanding continuance intention of mobile instant messaging: motivators and inhibitors. Ind Manag Data Syst 115(4):646-660

Mariano K (2018) Why hotels in China should strengthen their online bookings. https://www.traveldail ymedia.com/why-hotels-in-china-should-strengthen-their-online-bookings/ Accessed 31 Aug 2018

Morosan C, Jeong M (2008) Users' perceptions of two types of hotel reservation Web sites. Int J Hosp Manag 27(2):284-292

Morse JM (1991) Approaches to qualitative-quantitative methodological triangulation. Nurs Res 40(2):120-123

Nathan RJ, Victor V, Tan M, Fekete-Farkas M (2020) Tourists' use of Airbnb app for visiting a historical city. Inf Technol Tour 22(3):217-242

Nedungadi P (1990) Recall and consumer consideration sets: influencing choice without altering brand evaluations. J Consum Res 17(3):263-276

Neuman Y, Leibowits L, Schwarz B (2000) Patterns of verbal mediation during problem solving: a sequential analysis of self-explanation. J Exp Educ 68(3):197-213

Nikbin D, Hyun SS, Baharun R, Tabavar AA (2015) The determinants of customers' behavioral intentions after service failure: the role of emotions. Asia Pac J Tour Res 20(9):971-989

Nunnally JC (1978) Psychometric theory. McGraw-Hill, New York

Onwuegbuzie AJ, Dickinson WB, Leech NL, Zoran AG (2009) A qualitative framework for collecting and analyzing data in focus group research. Int J Qual Methods 8(3):1-21

Ozturk AB, Bilgihan A, Nusair K, Okumus F (2016) What keeps the mobile hotel booking users loyal? Investigating the roles of self-efficacy, compatibility, perceived ease of use, and perceived convenience. Int J Inf Manag 36(6, Part B):1350-1359 
Park S, Yin Y, Son B-G (2019) Understanding of online hotel booking process: A multiple method approach. J Vacat Mark 25(3):334-348

Patterson PG (2004) A contingency model of behavioural intentions in a services context. Eur J Mark 38(9/10):1034-1315

Ping RA (1993) The effects of satisfaction and structural constraints on retailer exiting, voice, loyalty, opportunism, and neglect. J Retail 69(3):320-352

Ponte EB, Carvajal-Trujillo E, Escobar-Rodriguez T (2015) Influence of trust and perceived value on the intention to purchase travel online: integrating the effects of assurance on trust antecedents. Tour Manag 47(4):286-302

Porter ME (1980) Competitive strategy. Free Press, New York

Qiu H, Ye B, Bai B, Wang W (2015) Do the roles of switching barriers on customer loyalty vary for different types of hotels? Int J Hosp Manag 46:89-98

Ram S, Jung H-S (1990) The conceptualization and measurement of product usage. J Acad Mark Sci 18(4):67-76

Roos R, Aswegen HV, Eales C (2002) Perceived effort of functional activities after a period of mechanical ventilation. S Afr J Physiother 58:33-36

Shim S, Eastlick MA, Lotz SL, Warrington P (2001) An online prepurchase intentions model: the role of intention to search. J Retail 77:397-416

Shiau WL, Luo MM (2012) Factors affecting online group buying intention and satisfaction: a social exchange theory perspective. Comput Hum Behav 28(6):2431-2444

Silva GLD, Mendes Filho L, Marques Júnior S (2019) Analysis of the perception of accommodation consumers on the use of online travel agencies (OTAs). Revista Brasileira de Pesquisa em Turismo 13(1):40-57

Statista (2016) Number of monthly active WeChat users from 2nd quarter 2010 to 2nd quarter 2016 (in millions). https://www.statista.com/statistics/255778/number-of-active-wechat-messenger-accounts/ Accessed 1 Mar 2016

Statista (2019) Digital travel sales worldwide from 2014 to 2020. https:/www.statista.com/statistics/ 499694/forecast-of-online-travel-sales-worldwide/. Accessed 9 Feb 2020

Su Q, Shao P, Ye Q (2011) An integrated analysis framework for customer value, customer satisfactory, switching barriers, repurchase intention and attitudinal loyalty: evidences from China mobile data services. Manag Sci Eng 5(3):135-142

Tanford S (2016) Antecedents and outcomes of hospitality loyalty: a meta-analysis. Cornell Hosp Q 57(2):122-137

Tao M, Nawaz MZ, Nawaz S, Butt AH, Ahmad H (2018) Users' acceptance of innovative mobile hotel booking trends: UK vs. PRC Inf Technol Tour 20(1-4):9-36

Tashakkori A, Teddlie CB (2010) SAGE handbook of mixed methods in social and behavioral research

Teng YM, Wu KS, Chou CY (2020) Price or convenience: what is more important for online and offline bookings? A study of a five-star resort hotel in Taiwan. Sustainability 12(10):3972

Tsai MT, Tsai CL, Chang HC (2010) The effect of customer value, customer satisfaction, and switching costs on. Soc Behav Pers Int J 38(6):729-740

Valeri M, Baggio R (2020a) Social network analysis: organizational implications in tourism management. Int J Organ Anal 29(2):342-353. https://doi.org/10.1108/IJOA-12-2019-1971

Valeri M, Baggio R (2020b) A critical reflection on the adoption of blockchain in tourism. Inf Technol Tour. https://doi.org/10.1007/s40558-020-00183-1

Valeri M, Baggio R (2020c) Italian tourism intermediaries: a social network analysis exploration. Curr Issues Tour. https://doi.org/10.1080/13683500.2020.1777950

Varma A, Jukic N, Pestek A, Shultz CJ, Nestorov S (2016) Airbnb: exciting innovation or passing fad? Tour Manag Perspect 20:228-237

Vryona D (2014) Investigating website usability and behavioural intention for online hotel reservations: a cognitive perspective. Brunel University

Yin CK, Shen H (2016) Assessing the Effects of Switching Costs on Perceived Values and Brand Loyalty: The Impact of Customers' Perceived Authenticity in Hotel Sector. Int J Bus Manage 12(1):84-94

Zhang S-N, Li Y-Q, Liu C-H, Ruan W-Q (2019) Critical factors in the identification of word-of-mouth enhanced with travel apps: the moderating roles of Confucian culture and the switching cost view. Asia Pac J Tour Res 24(5):422-442

Publisher's Note Springer Nature remains neutral with regard to jurisdictional claims in published maps and institutional affiliations. 